\title{
ガラス片迷入による小巟膝関節軟骨 ・半月損傷の一例
}

\author{
九州労災病院整形外科 \\ 佐 藤実・村 尾哲 \\ 井 原 秀 俊・野 村 茂 治
}

\section{A Case Report of Meniscus and Articular Cartilage Damaged by Broken Glass in the Knee}

by

Minoru Sato, Tetsu Murao, Hidetoshi Ihara

and Shigeharu Nomura

Department of Orthopaedic Surgery,

Kyushu Rosai Hospital, Fukuoka, Japan

We experienced a rare case of damage to the meniscus and articular cartilage caused by broken glass in the knee. Case: A 9-year-old boy injured his right knee with broken glass, which had previously been incompletely removed. Due to some pieces remaining in his knee, he still had right knee pain. On presentation to our hospital plane roentgenogram demonstrated two pieces of the glasses. Arthroscopic examination showed severe damage to both meniscus and articular cartilage. The glass pieces were removed arthroscopically and the patient returned to normal daily life with in 5 days with no knee complaints. However his damaged knee should be followed carefully. This case suggests the importance of the X-ray check and arthroscopy in cases of glass injury around the knee.

\section{はじめに}

膝関節は肘関節とともに関節内遊離体の頻発する関 節であるが，そのほとんどは離断性骨軟骨炎，骨折な どに伴う生体組織が遊離体となるものである，異物， 特にガラス片が軟部組織へ迷入しているのは日常診療 上良くみられるが，関節内まで迷入していることは少 ない. 今回, 初療時見逃された膝関節内のガラス片が 半月・関節軟骨を著しく損傷させた小児例を経験した ので，その所見，処置，および経過について報告し臨 床現場への警鐘としたい.

\section{症例}

症例： 9 才, 男性. 平成 3 年 8 月 1 日, 自宅で転倒 し空ガラスで右膝蓋骨内側部に約 $2 \mathrm{~cm}$ の挫創を受傷 した。この際, 窓ガラスは粉々に割れたという。近医 にて挫創の縫合および投薬をうけ帰宅. 疼痛あったが
歩行していたという。ところが徐々に膝が腫脹し, 穿 刺にて血腫が認められた。単純 X線像にガラス陰影を 認めたため 3 日後同医にて摘出を試みられたが，完全 には除去できなかった，以後, 歩行時膝関節痛は徐々 に消褪し膝関節血症の再発もなかったが，膝屈曲時の 疼痛が消失しないため 8 月 22 日当院を受診した。

初診時, 右膝には熱感・発赤・腫脹などなく歩行は 正常に可能であったが, 膝を 110 度以上屈曲すると疼 痛を生じた. 8 月 22 日当院初診時の単純 $\mathrm{X}$ 線像で 2 個のガラス陰影を認め, 2 週後の単純 X線像では外側 のガラス陰影が移動しているのが判明した（図 1 ).

9 月 9 日, 腰椎麻酔下に関節鏡検査を行った.

外側および内側膝蓋下アプローチよりみた鏡視所見 では，ガラス片が内側半月中節および外側半月中節に 埋入しており，各半月中節部はズタズタにひき裂かれ ていた，そればかりか，埋入したガラス片に接する大 腿骨顆部の関節軟骨も著しく損傷していた（図 2 ）. 


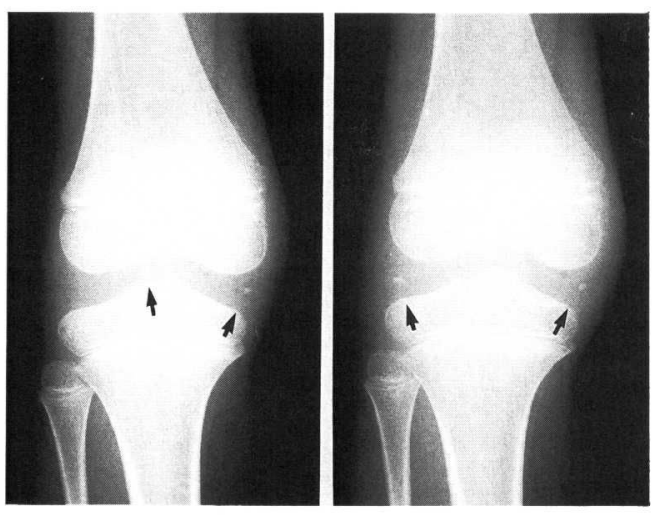

図 1 左は 8 月 22 日当院初診時の, 右は 9 月 4 日入 院時の単純 $\mathrm{X}$ 線像を示す. 2 個のガラス陰影を 認め, 外側のものは移動している.
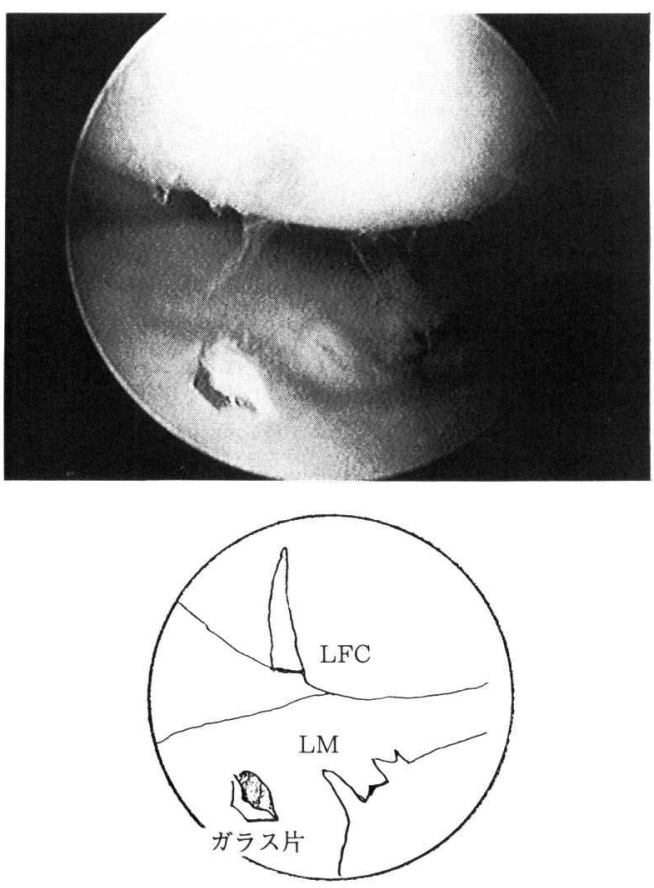

図 2 外側半月に埋入したガラス片を示す. それに接 する大腿骨顆部の関節軟骨には, 縦溝が入り傷 ついている。

ガラス片は半月に埋まり込んでいたため鏡視下に 18 ゲージ針で半月より押し出し，䯣核鉗子にて米粒大の ガラス片を 2 個摘出した（図 3 ). 術後 2 日めより膝 関節運動を開始し, 3 日めには荷重を開始した. 術前 のような疼痛は全く認められず，5日めに独歩退院し た. 術後 8 カ月を経過した現在, 膝には疼痛なく可動

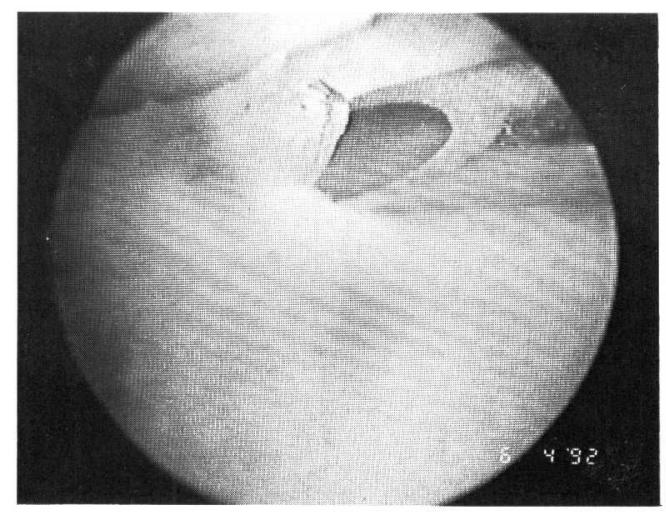

図 3 半月内に埋入したガラス片を 18 ゲージ針にて 押し出し, 髄核鉗子にて摘出した.

域制限もない。体育の授業にも通常通り参加しており, $\mathrm{ADL}$ 上の支障もない.

\section{考察}

膝関節内遊離体の報告は多いが，そのほとんどは自 己組織由来のもので異物によるものは少ない. 遊離体 が自己組織由来のものであった場合, 滑膜に取り込ま れ吸収の方向へ向かうことが多く ${ }^{2}$ 必ずしも摘出が必 要とは限らない，遊離体がガラス片などの異物であっ た場合も，感染などなければ滑膜に取り込まれて瘉着 し移動しないことが多いと考えられるが, 異物は残存 したままであり関節炎や関節運動障害を惹起する可能 性が残る(1)3(4)5/6)7). 過去の報告例をみても, ガラス 片が膝関節に迷入後 6 年間無症状であった 46 才女性 が化膿性膝関節炎を起こしたり ${ }^{5)}$, やはり 6 年間無症 状であった 21 才男性に膝関節血症が続発したもの4) もある. 自験例は異物により関節構成体損傷を来した 稀な例であり, 関節軟骨のこのような著しい損傷は変 形性膝関節症への早期の移行が危惧される.

今回の症例のように幼小児では, 病歴がはっきりし ないうえ安静が保てないことも多く, 損傷を増加させ る可能性も高い. そのため, 初療時には受傷機序に注 意してよく問診し, 異物迷入の可能性があれば少なく とも単純 X線撮影を行っておくべきである. 単純 X線 像に異常なくても疼痛持続など臨床的に異物迷入の可 能性が残れば, Echo. CT. MRI どの画像診断手段 を適切に選択し, 最終的には関節鏡まで検査を進める ベきであろう。 
今回の症例では成長に伴い損傷された半月および関 節軟骨による障害が懸念されるため，MRI なども用 いた経過観察が必要であり再鏡視も考慮している.

\section{結語}

(1)初療時，見逃されたガラス片迷入による小児膝関 節軟骨・半月損傷の 1 例を経験した.

(2)膝周囲の挫創など異物迷入の可能性があれば，少 なくとも単純 X線撮影は行うべきである.

(3)単純 X線像に異常なくても疼痛持続など臨床的に 異物迷入の可能性が残れば, 迷わず Echo. CT. MRI. 最終的には関節鏡まで検査を進めるべきである。

\section{参 考 文 献}

1) O'connor, C. R. et. al.: Foreign Body Reactions Simulating Acute Septic Arthritis. J Rheumatol., 15 : (10), 1568-1571, 1988.

2) 福島 統ほか: 滑膜の吸収に関する組織化学的研究. リンパ学, $7:(1), 59-60,1984$.

3）黑木秀尚ほか: 膝関節内異物の 1 例. 広島医, $39:(8)$, 1319, 1986.

4) 中村博行ほか: 膝関節内異物の 1 例. 逓信医, $40:(6)$, $374,1988$.

5）中野哲雄ほか: 膝関節内異物の 2 症例. 整形外科と災 害外科, $33:$ : (4), 1158-1160, 1985.

6）西野敏温ほか：確定診断が困難であった膝関節内異物 の 1 例. 関東整災外会誌, $15:(3), 381,1984$.

7）山内一功ほか : ガラス小片膝関節内迷入により関節痛 を来した 1 例. 北海道整形災害外科雑誌, $23: 134,1978$. 